Article

\title{
Bio-Pellet Fuel from Oil Palm Empty Fruit Bunches (EFB): Using European Standards for Quality Testing
}

\author{
Anna Brunerová ${ }^{1, *}$, Miroslav Müller ${ }^{1}$, Vladimír Šleger ${ }^{2} \mathbb{1}$, Himsar Ambarita ${ }^{3}$ and Petr Valášek ${ }^{1}$ \\ 1 Department of Material Science and Manufacturing Technology, Faculty of Engineering, Czech University of \\ Life Sciences Prague, Kamýcká 129, 16500 Prague, Czech Republic; muller@tf.czu.cz (M.M.); \\ valasekp@tf.czu.cz (P.V.) \\ 2 Department of Mechanical Engineering, Faculty of Engineering, Czech University of Life Sciences Prague, \\ Kamýcká 129, 16500 Prague, Czech Republic; sleger@tf.czu.cz \\ 3 Department of Mechanical Engineering, Faculty of Engineering, University of Sumatera Utara, Jl. Abdul \\ Hakim No.1, Padang Bulan, Medan Baru, Kota Medan, Sumatera Utara 20222, Indonesia; himsar@gmail.com \\ * Correspondence: brunerova@tf.czu.cz; Tel.: +420-737-077-949
}

Received: 24 October 2018; Accepted: 22 November 2018; Published: 27 November 2018

\begin{abstract}
The oil palm (Elaeis guineensis Jacq.) represents Indonesian major agriculture crop, nevertheless, its cultivation and processing results in an excessive amount of waste biomass, namely, empty fruit bunches (EFB), which is not always properly processed or reused. Therefore, the present investigation was performed to attract wide public interest in proper waste management and reuse of waste biomass. The suitability of such waste biomass for bio-pellet fuel production within its ecological EFB reuse was the subject of investigation. Its fuel parameters, mechanical quality and microscopic analysis represented the set of experimental testing performed within the target purpose. Satisfactory result values were stated within oil palm EFB fuel parameters, namely, moisture content $M_{c}-7.07 \%$, ash content $A_{c}-9.41 \%$ and energy potential $N C V-15.06 \mathrm{MJ} \cdot \mathrm{kg}^{-1}$. Mechanical analysis of the produced bio-pellet fuel proved outstanding results: Volume density $\rho-1440.01 \mathrm{~kg} \cdot \mathrm{m}^{-3}$ and mechanical durability DU-97.4\% and 99.4\% (according to ÖNORM M 7135 (2003) and ISO 17831-1 (2015)). Furthermore, results of compressive strength $\sigma$ proved the requested high level; in simple pressure $\sigma_{p}-10.83 \mathrm{MPa}$ and in cleft $\sigma_{c}-60.46 \mathrm{~N} \cdot \mathrm{mm}^{-1}$. Stereoscopic microscope measurements proved a prevalent proportion of fiber $>97 \%$ within the feedstock content, and scanning electron microscopy (SEM) of bio-pellet samples diagnosed cracks purely on the outer surface, not within their internal structures, which indicated high quality compacted products. In conclusion, the overall evaluation indicates the production of environmental-friendly high quality bio-pellet fuel, thus, proving the suitability of oil palm EFB for the production of bio-pellet fuel.
\end{abstract}

Keywords: Indonesia; calorific value; mechanical durability; solid biofuel; waste biomass

\section{Introduction}

The Republic of Indonesia is one of the largest producers of palm oil, primarily originating from the oil palm (Elaeis guineensis Jacq.); the industry has produced the largest part of the country's income in recent years. Indonesia is by far the leading producer of palm oil; the cultivated area devoted to oil palm from 2014-2016 is about 8.5 million ha (Table 1). Overall, the palm oil crop is cultivated on 11 million ha in 42 countries [1]. Nevertheless, production of palm oil faces global criticism due to the serious, irrefutable environmental damage it causes. Cultivation of oil palm plantations contributes to the deforestation and degradation of tropical and subtropical areas, which have the most biologically diverse terrestrial ecosystems on Earth [2,3]. Also, cultivation practices often lead to purposefully set, but uncontrollable fires and to negative impacts on biodiversity of local animals: many endemic species 
(such as orang-utans, tigers or elephants and countless others) are purposely killed and threatened with extinction due to loss of habitat from the cultivation of new and existing plantations. Further, increased air pollution, including greenhouse gas emissions, was shown to be caused by the oil palm industry [4]. While cultivation of oil palm has been presented as a positive step for the economic situation of some specific countries [5], nevertheless, this may not take into account the devastating environmental consequences for humans, animals and ecosystems [4].

One way to reduce the negative impact of palm oil production is to follow the proper waste management of processing residues and ensure their subsequent utilization in an environmentally friendly manner. In general, approximately 55 tonnes of biological residues are annually produced on 1 ha oil palm plantation, which on average extracts about 5.5 tonnes of oil [6,7].

Table 1. Statistical data of oil palm fruit production in the Republic of Indonesia [8].

\begin{tabular}{|c|c|c|c|}
\hline \multirow{2}{*}{ Year } & Harvested Area & Yield & Production \\
\hline & (ha) & $\left(\mathrm{hg} \cdot \mathrm{ha}^{-1}\right)$ & (t) \\
\hline 2016 & $8,150,000$ & 171,721 & $139,952,542$ \\
\hline 2015 & $8,630,000$ & 172,731 & $149,066,849$ \\
\hline 2014 & $9,333,482$ & 171,571 & $160,135,795$ \\
\hline
\end{tabular}

\section{Potential Uses of Empty Fruit Bunches (EFBs)}

Among the by-products of palm oil production is a great amount of empty fruit bunches (EFBs) after the crude oil is extracted from harvested palm fruit bunches [6]. For example, one study estimated that 84.74 million tonnes of waste biomass was produced in palm oil mills in Malaysia in 2010, of which EFBs represented 19.3 million tonnes [9]; another study estimated 23.8 million tonnes of EFBs were produced in Malaysia in the same year [10]. However, only 30\% of the palm oil mills surveyed in [9] reused oil palm EFB for any other purposes.

EFBs have a great deal of potential for subsequent utilization. Studies have shown that EFBs are suitable for fast pyrolysis [11] and for microwave-assisted pyrolysis [12]. Other studies have shown EFBs could be used to produce sugars via cellulose and hemicellulose recovery [13]; polypropylene composites [1]; or bio-composites [6]. The studies of [14,15] have shown EFBs as a significant potential source of renewable energy in some areas. Other possible technological applications for EFBs were reviewed in $[9,16]$, namely, for production of ethanol, methane (biogas), pulp and paper, medium-density fibreboards, compost (bio-fertiliser), synthetic high density polyethylene (HDPE) or fuel for combined heat and power (CHP) plants.

The latter was investigated in [5], who demonstrated successful use of EFBs for energy generation, i.e., a waste biomass biofuel (including some fibre and shell biomass as well) intended for direct combustion processes for oil palm mill operation. While this minimized the mill's needs for any other electricity source, nevertheless, this investigation used the raw bulk form of EFBs, which considerably decreases its energy potential. Such limitations can be removed by the use of densification processes, which can increase the potential of EFBs for use in direct combustion for energy generation. Such processes were used on EFBs as a feedstock material for solid biofuel production [17,18]. Bio-pellet fuel production from EFBs and palm kernel shell (PKS) has been investigated with focus on steam explosion pre-treatment and its influence on the physical and mechanical properties of produced pellets $[19,20]$, while another study demonstrated the suitability of EFB pellets torrefaction [21].

As seen, oil palm EFBs have a great potential for a wider scope of utilization. Thus, the main aim of the present research was to analyse the microscopic, mechanical and fuel parameters of EFB bio-pellet fuel to assess whether they could meet international standards for pellet bio-fuels, and thus be a local, sustainable source for such fuels, thus improving the sustainability of the oil palm crop. 


\section{Materials and Methods}

All experimental investigations were conducted to mandatory technical standards of European Union, as stated by the European Committee for Standardization (CEN). Such standards define quality and safety requirements for solid biofuel commercial production, thus, ensure production of high-quality product. In consequence, the process of bio-pellet production is a combination of several procedures including suitable feedstock materials selection, production of the bio-pellet fuel itself and mechanical and chemical testing procedures of bio-pellet fuel final quality. The abovementioned standards define the correctness of all necessary production procedures, thus, the related standards used within present research are described in the sub-sections below. Specifically, the following standards were applied: ISO 16559 (2014): Solid biofuels-Terminology, definitions and descriptions [22], ISO 17225-6 (2014): Solid biofuels-Fuel specifications and classes-Part 6: Graded non-woody pellets [23] and ISO 17225-1 (2014): Solid biofuels—Fuel specifications and classes-Part 1: General requirements [24].

For better understanding of the methodology of the research, a flowchart that depicts the specific steps of performed experimental investigation is provided in Figure 1.
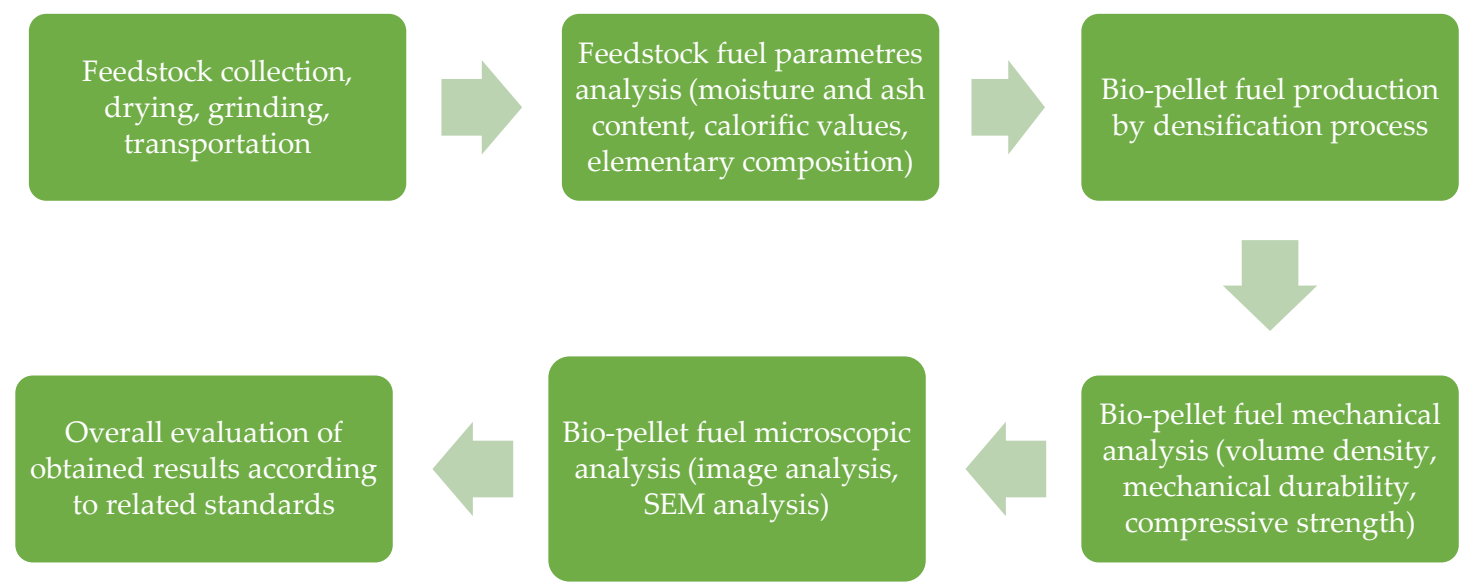

Figure 1. Specific steps of performed bio-pellet fuel samples investigation.

\subsection{Materials and Samples}

Empty fruit bunches from E. guineensis oil palm were obtained from a palm oil processing mill located close to the Pematang Siantar city, North Sumatra, Republic of Indonesia $\left(2^{\circ} 48^{\prime} 4^{\prime \prime} \mathrm{N}, 99^{\circ} 31^{\prime} 30^{\prime \prime}\right.$ E), as seen in Figure 2.

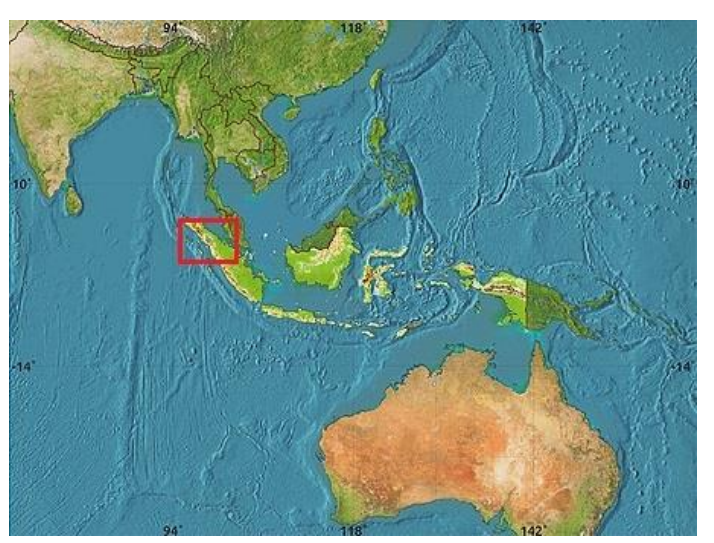

(a)

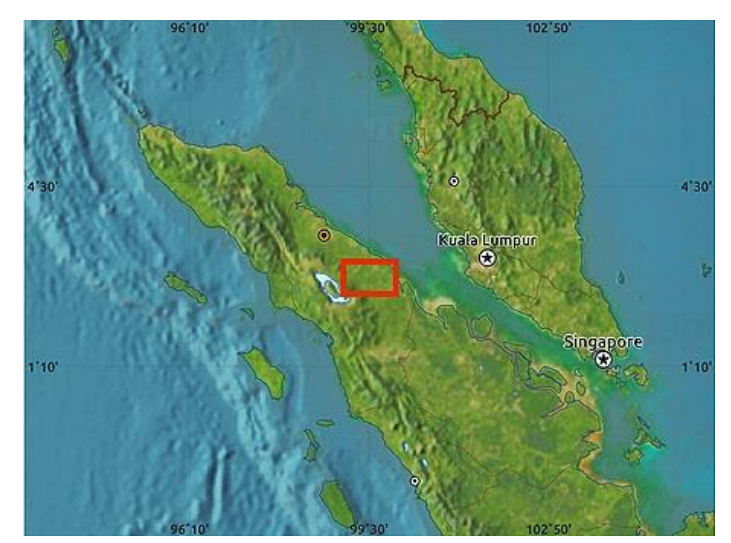

(b)

Figure 2. Locator map of processing mill and growing area of EFBs sampled: (a) Location of North Sumatra within the Republic of Indonesia; (b) Location of Pematang Siantar within North Sumatra [25]. 
Since the material originated from palm oil processing mill, the EFBs were already partly processed, i.e., dried and chopped into smaller lengths of fibre (Figure 3a). Further, the material prevalently contained EFB fibres, but also included the remains of shells and kernels and tiny particles as a dust (visible in Figure 3a). Such composition indicated that investigated material represented mixed biomass because it contained material from both herbaceous (fiber) and fruit (shells and kernels) origins.

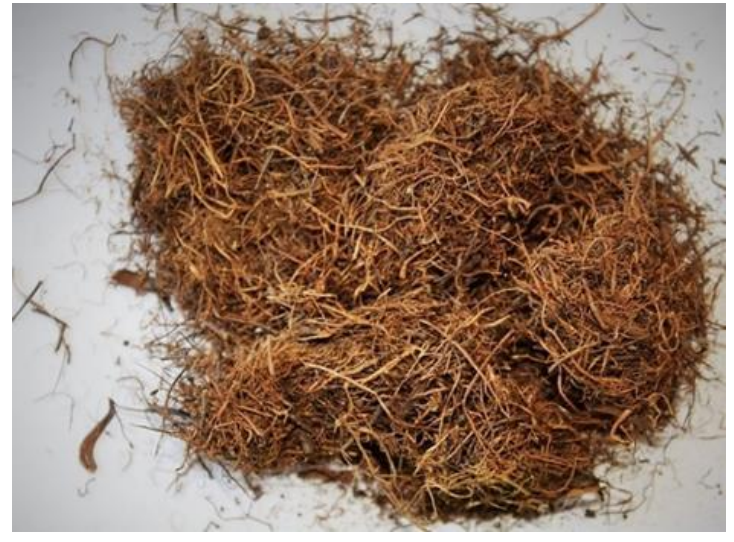

(a)

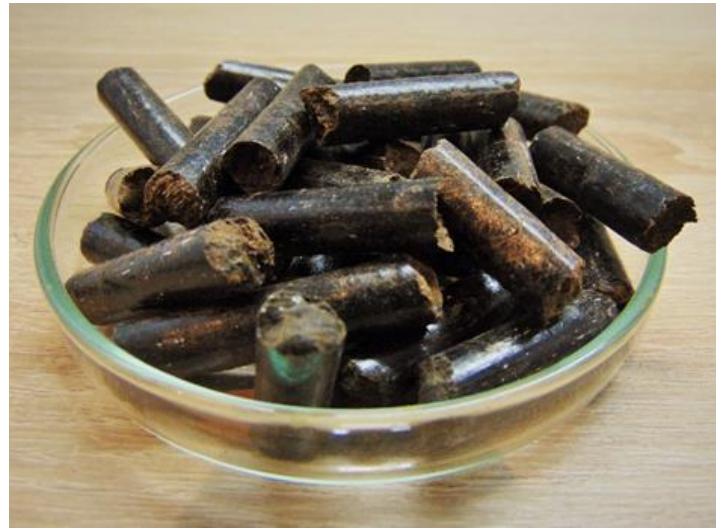

(b)

Figure 3. Investigated oil palm EFB: (a) In raw form; (b) in bio-pellet fuel form.

A non-branded pelletizer machine was used for successful production of $8 \mathrm{~mm}$-diameter bio-pellet samples; examples of samples produced are shown in Figure $3 \mathrm{~b}$.

The desired dimensions of the produced bio-pellet fuel were determined according to standard ISO 17829 (2015): Solid Biofuels-Determination of length and diameter of pellets [26], which defines proper pellet length as $3.15 \mathrm{~mm}<\mathrm{L} \leq 50 \mathrm{~mm}$. The precise dimensions of the bio-pellet samples are noted in Table 2.

Table 2. Dimensions of produced bio-pellet fuel samples.

\begin{tabular}{cccc}
\hline \multirow{2}{*}{ Biomass } & Length & Diameter & Weight \\
\cline { 2 - 4 } & $\mathbf{( m m )}$ & $\mathbf{( m m )}$ & $\mathbf{( g )}$ \\
\hline Oil palm EFB & $30.61 \pm 6.10$ & $8.71 \pm 0.22$ & $2.63 \pm 0.55$ \\
\hline \multicolumn{4}{c}{ \pm -standard deviation. }
\end{tabular}

\subsection{Fuel Parameter Analysis}

As investigated bio-pellet fuel was intended for use in direct combustion for energy (electricity) generation, the analysis of its fuel parameters played an important role in the final evaluation of its suitability for such purposes. The specific chemical parameters relevant to bio-pellet fuel safety for users and the environment were determined with the test equipment and according to the standards listed in Table 3. 
Table 3. List of assessed solid biofuel fuel parameters, European standards used, and test equipment.

\begin{tabular}{|c|c|c|}
\hline Parameter & ISO Standard & Equipment \\
\hline $\begin{array}{l}\text { Moisture content } M_{\mathcal{C}} \\
(\%)\end{array}$ & $\begin{array}{l}\text { ISO 18134-1 (2015): Solid biofuels-Determination of } \\
\text { moisture content-Oven dry method-Part 1: Total } \\
\text { moisture-Reference method [27] } \\
\text { ISO 18134-2 (2017): Solid biofuels-Determination of } \\
\text { moisture content-Oven dry method-Part 2: Total } \\
\text { moisture-Simplified method [28] }\end{array}$ & \multirow[t]{2}{*}{$\begin{array}{l}\text { Thermogravimetric } \\
\text { analyser LECO, Type } \\
\text { TGA } 701 \text { (Saint Joseph, } \\
\text { MO, USA) }\end{array}$} \\
\hline Ash content $A_{\mathcal{C}}(\%)$ & $\begin{array}{l}\text { ISO } 18122 \text { (2015): Solid biofuels-Determination of } \\
\text { ash content [29] }\end{array}$ & \\
\hline $\begin{array}{l}\text { Gross calorific value } \\
G C V\left(\mathrm{MJ} \cdot \mathrm{kg}^{-1}\right)\end{array}$ & $\begin{array}{l}\text { ISO } 18125 \text { (2017): Solid biofuels-Determination of } \\
\text { calorific value [30] }\end{array}$ & \multirow{2}{*}{$\begin{array}{l}\text { Isoperibol calorimeter } \\
\text { LECO, Type AC } 600 \\
\text { (Saint Joseph, MO, USA) }\end{array}$} \\
\hline $\begin{array}{l}\text { Net calorific value } \\
\operatorname{NCV}\left(\mathrm{MJ} \cdot \mathrm{kg}^{-1}\right)\end{array}$ & $\begin{array}{l}\text { ISO } 1928 \text { (2010): Solid mineral fuels-Determination } \\
\text { of gross calorific value by the bomb calorimetric } \\
\text { method and calculation of NCV [31] }\end{array}$ & \\
\hline $\begin{array}{l}\text { Carbon } C \text {, Nitrogen } \\
N, \text { Hydrogen } H(\%)\end{array}$ & $\begin{array}{l}\text { ISO } 16948 \text { (2015): Solid biofuels-Determination of } \\
\text { total content of carbon, hydrogen and nitrogen [32] }\end{array}$ & \multirow{2}{*}{$\begin{array}{l}\text { Laboratory equipment } \\
\text { LECO, Type CHN628+S } \\
\text { (Saint Joseph, MO, USA) }\end{array}$} \\
\hline Sulphur S (\%) & $\begin{array}{l}\text { ISO } 16994 \text { (2016): Solid biofuels-Determination of } \\
\text { total content of sulfur and chlorine [33] }\end{array}$ & \\
\hline
\end{tabular}

Results of all tested parameters were determined and processed using the test equipment and their related software, except net calorific value $N C V\left(\mathrm{MJ} \cdot \mathrm{kg}^{-1}\right)$ was calculated using the formula noted in related standard ISO 1928 (2010) [31]:

$$
N C V=G C V-24.42 \cdot\left(M_{c}+8.94 \cdot H\right)
$$

where $N C V$ refers to the net calorific value $\left(\mathrm{MJ} \cdot \mathrm{kg}^{-1}\right), G C V$ refers to the gross calorific value $\left(\mathrm{MJ} \cdot \mathrm{kg}^{-1}\right)$, 24.42 is the coefficient of $1 \%$ of water in the sample at $25^{\circ} \mathrm{C}, M_{c}$ refers to the moisture content in the analytical sample (\%), 8.94 is the coefficient of hydrogen to water conversion, and $H$ is the hydrogen content in the analytical sample (\%).

\subsection{Mechanical Analysis}

Experimental measurements were performed on the physical-mechanical properties of investigated feedstock materials and the produced bio-pellet samples, as well as the final mechanical quality of investigated bio-pellet fuel. Several mandatory mechanical quality indicators were determined according to related standards.

Primarily, bio-pellet samples of a minimum weight of $2000 \mathrm{~g}$ were divided according to ISO 18135 (2017): Solid Biofuels_Sampling [34], and properly prepared according to ISO 14780 (2017): Solid biofuels-Sample preparation [35]. After such preparation, the samples were subjected to experimental measurements performed according to the standards noted in Table 4.

The complete processes to determine the measurements indicated in Table 4 are described in detail below in the following sub-sections. The amount of fines produced $(F(\%))$, was determined by measuring the amount of fine material passing through a $40 \mathrm{~cm}$ sieve with $3.15 \mathrm{~mm}$ diameter round holes, shown in Figure 4. This value represented materials lost from the produced bio-pellet fuel, was determined by:

$$
F=m_{F} / m_{S} \cdot 100
$$

where: $F$ is the amount of fines (\%), $m_{F}$ is the mass amount of fines $(\mathrm{g}), m_{S}$ is the mass amount of samples (g) [36]. 
Table 4. List of used European standards related to solid biofuel mechanical parameters.

\begin{tabular}{lll}
\hline \multicolumn{1}{c}{ Parameter } & \multicolumn{1}{c}{ ISO Standard } & \multicolumn{1}{c}{ Equipment } \\
\hline $\begin{array}{l}\text { Amount of fines } \\
F(\%)\end{array}$ & $\begin{array}{l}\text { ISO 18846 (2016): Solid biofuels-Determination of } \\
\text { fines content in quantities of pellets [36] } \\
\text { ISO 3310-2 (2013): Test sieves-Technical } \\
\text { requirements and testing-Part 2: Test sieves of } \\
\text { perforated metal plate [37] }\end{array}$ & $\begin{array}{l}\text { Metal sieve with 3.15 mm } \\
\text { diameter round hole }\end{array}$ \\
\hline $\begin{array}{l}\text { Bulk density BD } \\
\left(\mathrm{kg} \cdot \mathrm{m}^{-3}\right)\end{array}$ & $\begin{array}{l}\text { ISO 17828 (2015): Solid biofuels-Determination of } \\
\text { bulk density [38] }\end{array}$ & $\begin{array}{l}\text { Stainless steel measuring } \\
\text { container }\end{array}$ \\
\hline $\begin{array}{l}\text { Volume density } \\
\rho\left(\mathrm{kg} \cdot \mathrm{m}^{-3}\right)\end{array}$ & $\begin{array}{l}\text { EN ISO 18847 (2016): Solid biofuels-Determination } \\
\text { of particle density of pellets and briquettes [39] }\end{array}$ & $\begin{array}{l}\text { Digital measuring instruments } \\
\text { Kern }\end{array}$ \\
\hline $\begin{array}{l}\text { Compressive } \\
\text { strength } \sigma(-)\end{array}$ & [40-43] & $\begin{array}{l}\text { Universal hydraulic machine } \\
\text { Labortech, Type MP Test 5.050 } \\
\text { (Opava, Czech Republic) }\end{array}$ \\
\hline \multirow{2}{*}{$\begin{array}{l}\text { Mechanical } \\
\text { durability DU } \\
(\%)\end{array}$} & $\begin{array}{l}\text { ISO 17831-1 (2015): Solid biofuels-Determination of } \\
\text { mechanical durability of pellets and briquettes-Part } \\
\text { 1: Pellets [4] }\end{array}$ & $\begin{array}{l}\text { Pellettester PT 500 (Prague, } \\
\text { Czech Republic) }\end{array}$ \\
\cline { 2 - 3 } & $\begin{array}{l}\text { ÖNORM M 7135 (2003): Compressed wood or } \\
\text { compressed bark in natural state, pellets and } \\
\text { briquettes. Requirements and test specifications [45] }\end{array}$ & $\begin{array}{l}\text { Lingo-tester Tekpro Limited, } \\
\text { type New Holmen Tester } \\
\text { (Norfolk, UK) }\end{array}$ \\
\hline
\end{tabular}

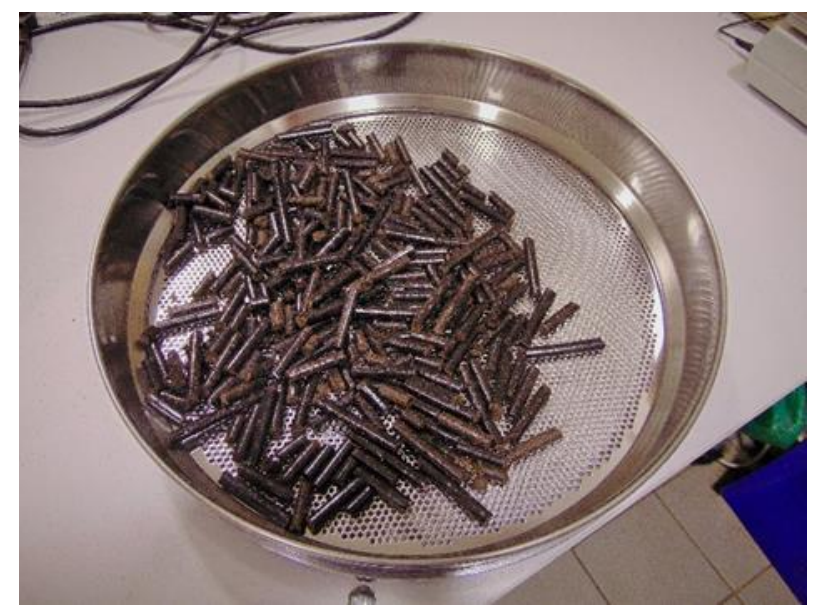

Figure 4. Metal sieve used to determine amount of fines produced $(F(\%))$ with $3.15 \mathrm{~mm}$-diameter round holes.

Bulk density $(B D)\left(\mathrm{kg} \cdot \mathrm{m}^{-3}\right)$, represented the suitability of bio-pellet fuel for packaging, handling, transhipment or transportation. As per the standard's instructions, the following formula was used to calculate $B D)$ :

$$
B D=\left(m_{2}-m_{1}\right) / V_{c}
$$

where $B D$ is the bulk density $\left(\mathrm{kg} \cdot \mathrm{m}^{-3}\right), m_{2}$ is the weight of the filled container $(\mathrm{kg}), m_{1}$ is the weight of the empty container $(\mathrm{kg})$ and $V$ is the container volume $\left(\mathrm{m}^{3}\right)$ [35].

The efficiency of the densification process can be also evaluated according to the volume density $\rho\left(\mathrm{kg} \cdot \mathrm{m}^{-3}\right)$ of the final solid biofuel products. Thus, the value of $\rho$ of the EFB bio-pellet fuel was calculated as:

$$
\rho=m / V
$$

where $\rho$ is the volume density $\left(\mathrm{kg} \cdot \mathrm{m}^{-3}\right), m$ is the samples mass $(\mathrm{kg})$, and $V$ is the samples volume $\left(\mathrm{m}^{3}\right)$ [39]. 
Compressive strength $\sigma$ is used for the determination of resistance to compressive stress caused by the weight of bio-pellet samples stored on top of each other, thereby simulating possible damage to the solid biofuel caused by storage, transportation or handling. It is an important parameter for logistics. In general, it expresses the maximum increasing load, which a specific sample can absorb before its integrity is breached [46]. The process of measurement was not conducted to any technical standard, however, it was based on previous research related to the strength of solid biofuels or other pressed products [40-43]. Two different types of such indicators were experimentally tested, namely, compressive strength $\sigma_{p}$ in simple pressure (MPa) and compressive strength in cleft $\sigma_{c}\left(\mathrm{~N} \cdot \mathrm{mm}^{-1}\right)$. Measurements were performed by the universal testing machine Labortech, type MP Test 5.050 (Opava, Czech Republic) equipped by a force meter KAF-S with range of 0-5000 N (accuracy used of $0.1 \mathrm{~N})$. The device was calibrated and verified in accordance to standard ISO 7500-1 (2018) [47]. The pressing speed $v_{p}$ was equal to $1 \mathrm{~mm} \cdot \mathrm{min}^{-1}$ and the software Test and Motion, version 4.2.17 (Opava, Czech Republic), was used for determination of resulting values. The bio-pellet samples were placed between two flat parallel jaws, horizontally for the cleft test and vertically for the simple pressure test. The maximal load $F_{\max }(\mathrm{N})$, recorded at the moment of bio-pellet sample rupture, was subsequently used for determination of specific compressive strength $\sigma$ by using the formulas given below.

For compressive strength $\sigma_{p}$ in simple pressure (MPa):

$$
\sigma_{p}=F_{\max } / A
$$

where $\sigma_{p}$ is compressive strength in simple pressure (MPa), $F_{\max }$ is the maximal load $(\mathrm{N}), A$ is cross-sectional area $\left(\mathrm{m}^{2}\right)$ and for compressive strength $\sigma_{c}$ in cleft $\left(\mathrm{N} \cdot \mathrm{mm}^{-1}\right)$ :

$$
\sigma_{c}=F_{\max } / L
$$

where $\sigma_{c}$ is the compressive strength in cleft $\left(\mathrm{N} \cdot \mathrm{mm}^{-1}\right), F_{\text {max }}$ is the maximal load $(\mathrm{N})$ and $L$ is the bio-pellet samples length $(\mathrm{m})$ [40].

Finally, mechanical durability $(D U(\%))$, which is considered the most important indicator of solid biofuel mechanical quality, describes the abrasion resistance (material loses) of tested samples. Due to its importance, there are several processes for its determination. Here, two different testing methods were used (as noted in Table 4). First, the tumbling can test was performed using standard ISO 17831-1 (2015) [44] with the tumbling can Pellettester PT 500 device (see Figure 5). The PT 500 device is equipped with rotation vessels that ensure controlled impacts of inserted bio-pellet samples while it is in operation. The PT 500 was constructed, tested and calibrated by the Research Institute of Agricultural Engineering, p.r.i. (Prague, Czech Republic).

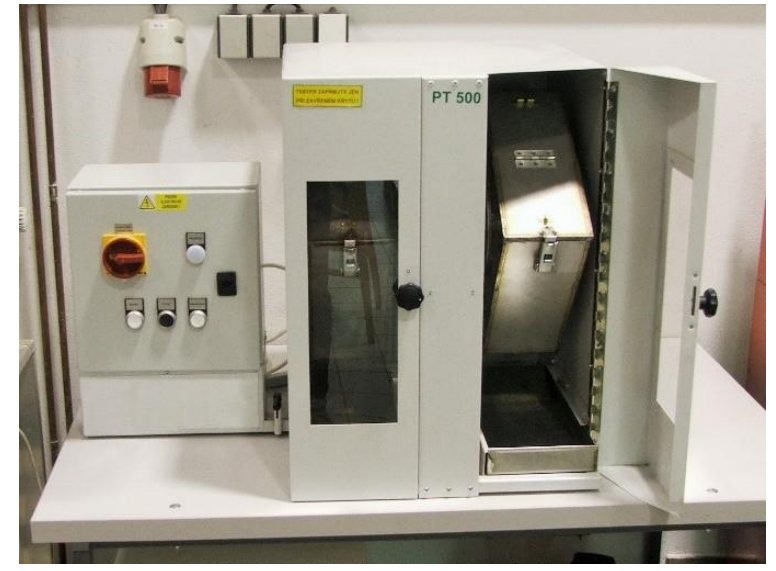

(a)

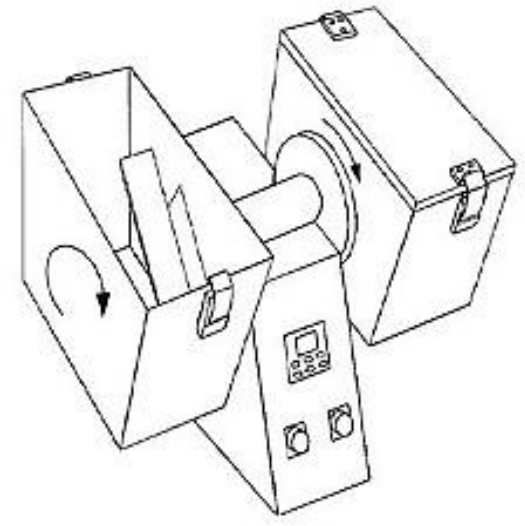

(b)

Figure 5. Tumbling can Pellettester PT 500 (ISO 17831-1, 2015): (a) In practice, (b) scheme. 
Result values were calculated by using the following formula (Equation (7)):

$$
D U=\left(m_{A} / m_{E}\right) \cdot 100
$$

where $D U$ is the mechanical durability (\%), $m_{A}$ is the mass of sieved pellets after the tumbling treatment $(\mathrm{g})$, and $m_{E}$ is the mass of the pre-sieved pellets before the tumbling treatment (g) [44].

Final bio-pellet samples mechanical durability $D U(\%)$ was expressed in the form of the percentage of fines after testing.

For the second test, $D U$ was measured using a similar principle, i.e., the bio-pellet samples were also subjected to controlled impacts in a closed vessel. However, this time, air flow was used to move the bio-pellet samples and cause abrasion. This testing method was conducted to the Austrian standard ÖNORM M 7135 (2003) [45], and testing device was the Lingo-tester Tekpro Limited, type New Holmen Tester (Norfolk, United Kingdom), shown in Figure 6.

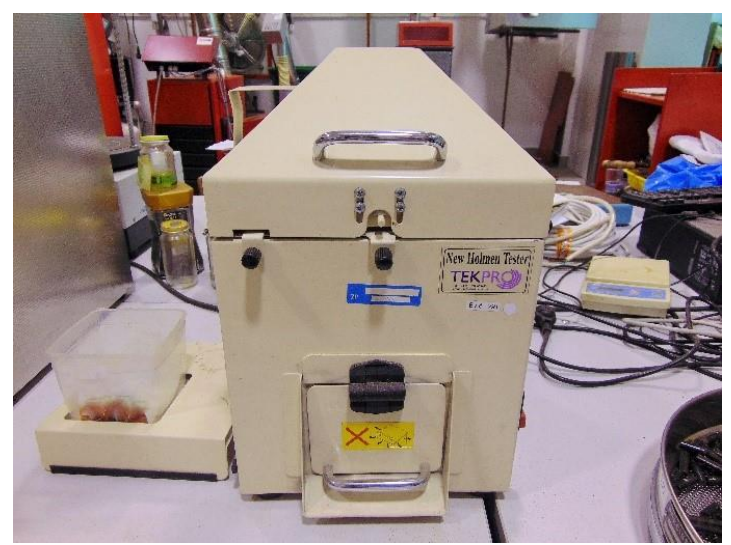

(a)

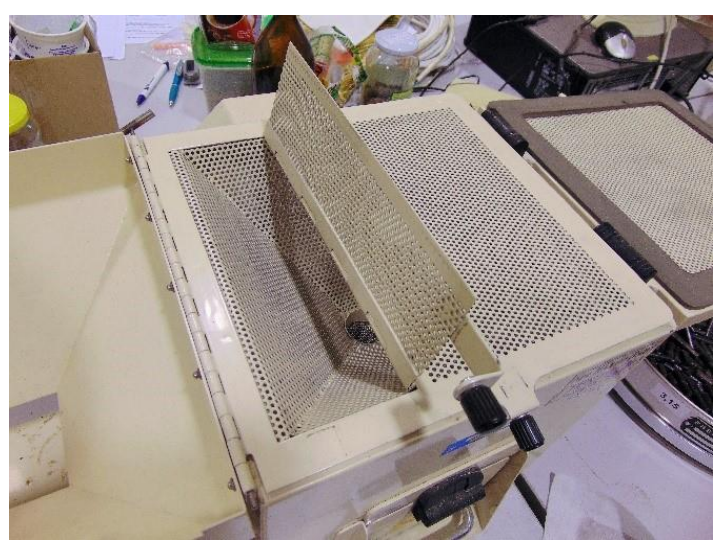

(b)

Figure 6. The New Holmen Tester pellet durability tester: (a) outside of testing device, (b) abrasion chamber.

Mechanical durability $D U$ here is equal to $A R$, the $\%$ of material that was abraded off during the testing, has been expressed in the form of the percentage of fines after testing [45]:

$$
A R=\left(m_{E}-m_{A} / m_{E}\right) \cdot 100
$$

where $A R$ is abrasion (\%), $m_{A}$ is the mass of sieved pellets after the tumbling treatment $(\mathrm{g})$, and $m_{E}$ is the mass of pre-sieved pellets before the tumbling treatment $(\mathrm{g})$ [45].

The difference between those two tests consists of expression of result values; the ISO 17831-1 (2015) [44] test results represent the percentage of material which remains in the form of the bio-pellet samples, while ÖNORM M 7135 (2000) [45] test results express the amount of material which was abraded from the bio-pellet samples off. Nevertheless, both of the methods described the same bio-pellet fuel quality indicator, the Mechanical durability $D U(\%)$.

\subsection{Microscope Analysis}

Simple image analysis of raw oil palm EFB feedstock material was performed by a Zeiss type Stemi 508 (Oberkochen, Germany) stereoscopic microscope with an Axiocam and supporting software (Figure 7a). In order to further observe the morphological features of the feedstock material as well as the EFB bio-pellet sample surfaces, a scanning electron microscope (SEM) analysis was conducted with a TESCAN, type MIRA 3 GMX SEM under a voltage of $5 \mathrm{kV}$ (Figure $7 \mathrm{~b}$ ); the samples were dusted with gold by the sputter coater equipment (rotary pumped) Quorum, type Q150R ES (Darmstadt, Germany)—Sputtering Deposition Rate using Gold. 


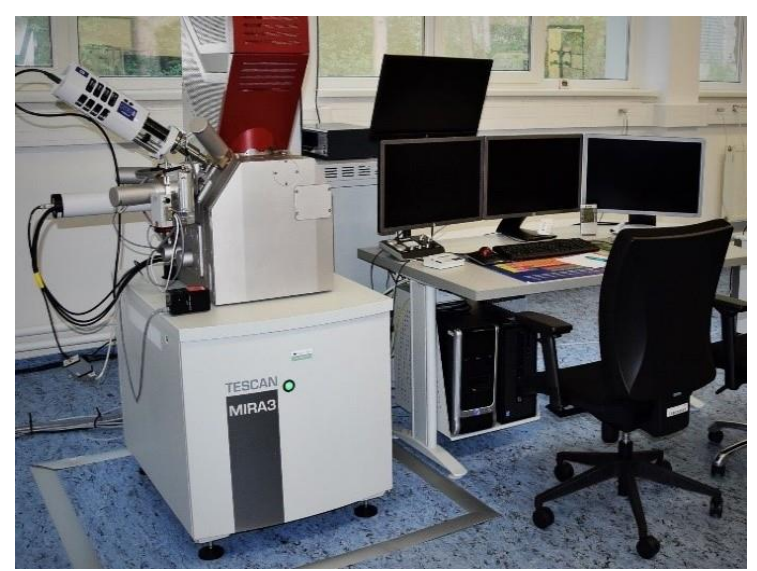

(a)

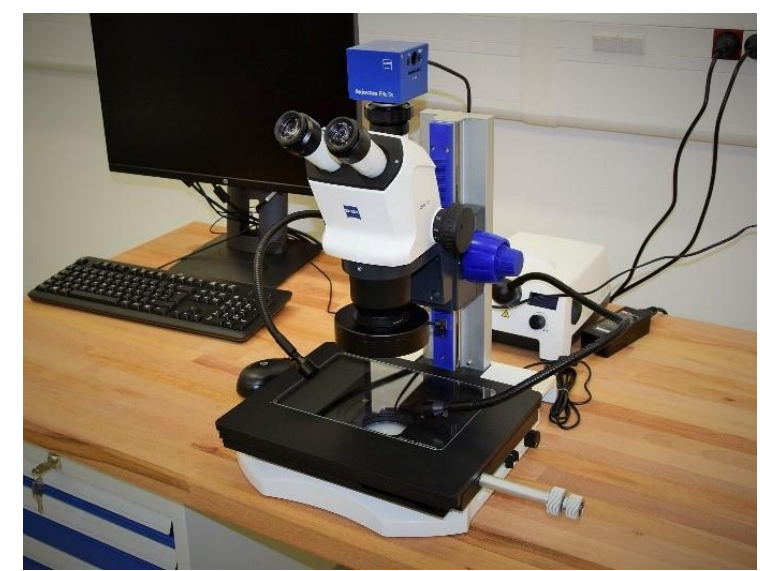

(b)

Figure 7. Equipment used for microscopic analysis: (a) stereoscopic microscope, (b) scanning electron microscopy (SEM).

In attempt to state the types of binding forces between the feedstock particles, SEM images of EFB bio-pellet fracture areas and surfaces were taken (labelled as (a) and (b), respectively, in Figure 8), as well as feedstock EFB fibres and particles.

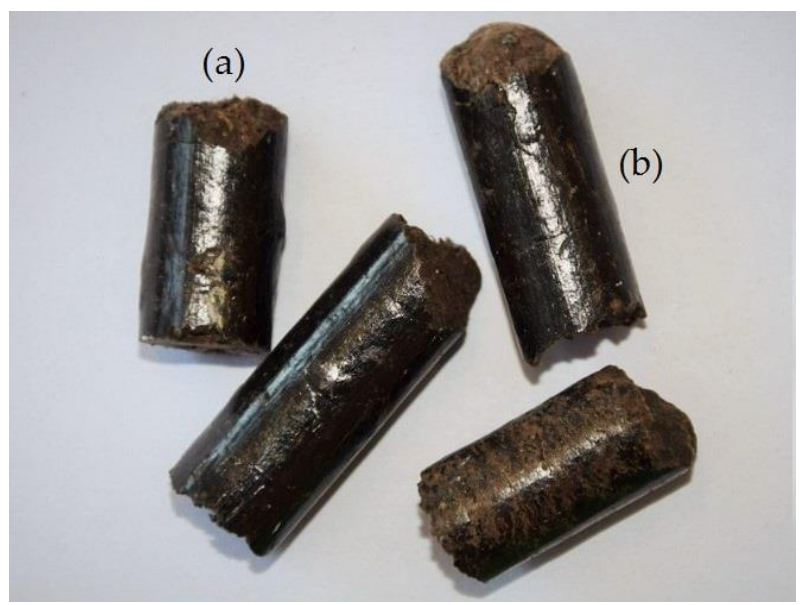

Figure 8. Bio-pellet samples areas subjected to the structure analysis: (a) fracture area, (b) outer surface.

\subsection{Statistical Analysis}

Result data were primarily organized and sorted and converted into graphs and tables using Microsoft Office Excel (Microsoft Redmond, Redmond, WA, USA). Subsequently, selected data were analysed with STATISTICA (TIBCO Software Inc., Tulsa, OK, USA), including the generation of descriptive statistics. An ANOVA was used for statistical analysis of mechanical durability $D U$ tested according to the two different methods (i.e., following the requirements of ISO 17831-1 (2015) and ÖNORM M 7135 (2000)) with a decision criteria of $p>0.05$.

\section{Results and Discussion}

In general, bio-pellet fuel final quality directly depends on its mechanical, chemical and microscopic properties [48], thus, observation of the abovementioned quality indicators represents a necessary step in order to ensure high-quality production and to assess the suitability of EFB and EFB pellets as a potential biofuel. 


\subsection{Fuel Parameter Analysis}

The fuel parameters of feedstock EFB, i.e., the basic chemical parameters, energy potential and elementary composition values are shown in Table 5. Unfilled cells in Table 5 mean there was no required level of that specific indicator stated in the relevant standards.

Table 5. Fuel parameters of oil palm empty fruit bunches (EFB) on a wet and dry basis on average.

\begin{tabular}{cccc}
\hline \multirow{2}{*}{ Indicator } & \multicolumn{2}{c}{ Result } & Standard \\
\cline { 2 - 3 } & in w. b. & in d. b. & \\
\hline$M_{\mathcal{C}}(\%)$ & 7.07 & - & $\leq 15[27,28]$ \\
$A_{c}(\%)$ & 9.41 & 10.12 & $\leq 10[29]$ \\
$G C V\left(\mathrm{MJ} \cdot \mathrm{kg}^{-1}\right)$ & 16.32 & 17.56 & - \\
$N C V\left(\mathrm{MJ} \cdot \mathrm{kg}^{-1}\right)$ & 15.06 & 16.39 & $\geq 14.5[30]$ \\
$C(\%)$ & 42.54 & 45.78 & - \\
$H(\%)$ & 5.80 & 5.39 & - \\
$N(\%)$ & 0.75 & 0.81 & $\leq 2.0[32]$ \\
$S(\%)$ & 0.13 & 0.14 & $\leq 0.3[33]$ \\
$O(\%)$ & - & 37.76 & - \\
\hline
\end{tabular}

$M_{c}$-moisture content, $A_{c}$-ash content, $G C V$-gross calorific value, $N C V$-net calorific value, $C$-Carbon, $\mathrm{H}$-Hydrogen, $\mathrm{N}$-Nitrogen, $S$-Sulphur, $\mathrm{O}-$ Oxygen.

The obtained results were compared to the mandatory technical standards, which define the requirements for solid (i.e., bio-pellet) biofuel quality, to determine whether EFB pellets are an appropriate biofuel commodity suitable for commercial sale.

The level of moisture content $\left(M_{\mathcal{C}}(\%)\right)$, shown in Table 5, corresponded to the result values of tested samples that had been previously processed (dried) in the Czech Republic, thus, it did not represent the initial moisture content of the just-produced waste biomass. Note that the initial moisture content level of EFB has been reported to be from $60.00-67.00 \%$ [15,49,50]. For the purposes of solid biofuel production moisture content had to be reduced to less than $15 \%$, otherwise it would not be possible to produce the bio-pellet fuel.

Comparison of the observed results presented in Table 5 for ash content $\left(A_{c}(\%)\right)$ and $N C V$ (net calorific value) with values from other studies (shown in Table 6) especially indicated higher (not required) levels of $A_{c}$ in our study. Such a result may have been caused by the samples being contaminated by impurities such as dust or soil. It could also indicate possible damage to the combustion equipment such as fouling or slagging during thermal conversion [18]. Although the increased values are not otherwise critical, it can be regarded as a limitation of the investigated materials. 
Table 6. Comparison of main oil palm EFB feedstock fuel parameters.

\begin{tabular}{ccc}
\hline Indicator & Result & Reference \\
\hline & 7.55 & {$[17]$} \\
$A_{\mathcal{C}}(\%)$ & 7.30 & {$[5]$} \\
& 4.70 & {$[17]$} \\
& 4.56 & {$[18]$} \\
Wood biomass ${ }^{*} A_{\mathcal{c}}(\%)$ & 5.47 & {$[19]$} \\
& 4.90 & {$[51]$} \\
\hline & $<1 \%$ & {$[52]$} \\
\hline & 16.64 & {$[17]$} \\
& 15.82 & {$[53]$} \\
& 17.00 & {$[54]$} \\
Wood biomass ${ }^{*} \mathrm{NCV}\left(\mathrm{kg}{ }^{-1}\right)$ & 18.05 & {$[55]$} \\
& 17.57 & {$[18]$} \\
$A_{c}$ - $\left.{ }^{-1}\right)$ & 18.54 & {$[19]$} \\
& $19.15-19.75$ & {$[52]$} \\
\hline
\end{tabular}

The energy potential, represented by the net calorific value $(\mathrm{NCV})\left(\mathrm{MJ} \cdot \mathrm{kg}^{-1}\right)$ described the amount of energy released during combustion processes of unit mass of fuel, thus, is the most important indicator of fuel chemical quality. The comparison of observed $N C V$ values $\left(15.06 \mathrm{MJ} \cdot \mathrm{kg}^{-1}\right.$; Table 5) with other study data (Table 6) showed a satisfactory result, but nonetheless lower than the data in Table 6 . Such results could be caused by the fact that investigated material contained $97 \%$ fibre, while higher calorific values are commonly ensured by the presence of residual oil from shells, nuts or kernels [56]. Unfortunately, the content of EFB (percentages of fibre, shell, kernel, etc.) of the samples used by other authors were not available. For better understanding of the evaluation of discussed data, values of wood waste biomass, namely, of spruce and pine woodchips, were also included [52].

The elemental composition of the EFB feedstock (Table 5) were typical for such material, as can be seen when compared to those seen in the studies listed in Table 7. The suitable percentage of oxygen is not strictly stated by any standard, thus, its level predicts the behaviour of bio-pellet fuel during combustion processes, while a lower level is required $(<40 \%)$. If compare observed and published data, it is seen that observed results predicts optimal behaviour of the investigated EFB.

Table 7. Comparison of oil palm EFB feedstock elemental composition in \%.

\begin{tabular}{cccccc}
\hline \multicolumn{7}{c}{ Indicator } & \multirow{2}{*}{ Reference } \\
\cline { 1 - 4 } $\boldsymbol{C}$ & $\boldsymbol{H}$ & $\boldsymbol{N}$ & $\boldsymbol{S}$ & $\boldsymbol{O}$ & \\
\hline 48.80 & 6.30 & 0.20 & 0.20 & 36.70 & {$[5]$} \\
45.14 & 6.05 & 0.54 & 0.20 & 48.08 & {$[21]$} \\
47.20 & 6.00 & 0.60 & 0.12 & 38.20 & {$[55]$} \\
42.99 & 6.19 & 0.64 & 0.08 & 50.11 & {$[17]$} \\
45.53 & 5.89 & 0.45 & - & 43.40 & {$[53]$} \\
\hline \multicolumn{4}{c}{ C-Carbon, H-Hydrogen, $N$-Nitrogen, S-Sulphur, O-Oxygen. }
\end{tabular}

As was observed by [57], a higher C content is commonly related to a higher NCV; carbon and hydrogen percent content is largely responsible for energy content in biofuels [58]. As such the lower level of carbon $(42.54 \%)$ in the present measurements are accompanied by lower NCV level (15.06 $\left.\mathrm{MJ} \cdot \mathrm{kg}^{-1}\right)$; compare the data in Tables 6 and 7 for the reference studies.

The measurement of oil palm EFB fuel parameters in dry ash free state (d.a.f.) was also performed, and the results are presented in Table 8. Such measurements are important, because the presence of the ash can influence the resultant values; in addition, as noted above the present samples had slightly higher observed ash contents than the reference studies. 
Table 8. Average fuel parameters of oil palm EFB feedstock in dry ash free state (d.a.f.).

\begin{tabular}{|c|c|c|c|c|c|c|}
\hline$C$ & $H$ & $N$ & $S$ & $O$ & $G C V$ & $N C V$ \\
\hline$(\%)$ & $(\%)$ & $(\%)$ & $(\%)$ & $(\%)$ & $\left(\mathrm{MJ} \cdot \mathrm{kg}^{-1}\right)$ & $\left(\mathrm{MJ} \cdot \mathrm{kg}^{-1}\right)$ \\
\hline 50.94 & 5.99 & 0.90 & 0.16 & 42.01 & 19.54 & 18.24 \\
\hline
\end{tabular}

Nevertheless, comparison of elementary composition result values in Tables 5 and 8 showed that there was little difference, except in \% oxygen.

\subsection{Mechanical Analysis}

The mechanical qualities tested of produced bio-pellet fuels focused on the strength and damage resistance of the pellets, i.e., the amenability of EFB to densification processes and successful pelletization. The values of the mechanical quality indicators are noted in Tables 9 and 10.

Table 9. Analysis of oil palm EFB bio-pellet fuel mechanical quality.

\begin{tabular}{ccc}
\hline Indicator & Result & Standard \\
\hline$F(\%)$ & 0.40 & $\leq 3.0[36]$ \\
$B D\left(\mathrm{~kg} \cdot \mathrm{m}^{-3}\right)$ & 758.12 & - \\
$\rho\left(\mathrm{kg} \cdot \mathrm{m}^{-3}\right)$ & $1440.01 \pm 79.25$ & $\geq 600[38]$ \\
$\sigma_{p}(\mathrm{MPa})$ & $10.83 \pm 2.94$ & - \\
$\sigma_{c}\left(\mathrm{~N} \cdot \mathrm{mm}^{-1}\right)$ & $60.46 \pm 9.61$ & - \\
\hline
\end{tabular}

F-amount of fines, $B K$-bulk density, $\rho$-volume density, $\sigma_{p}$-compressive strength in simple pressure, $\sigma_{c}$-compressive strength in cleft, \pm -standard deviation.

Table 10. Mechanical durability $D U(\%)$ of tested bio-pellet samples according different standards.

\begin{tabular}{ccc}
\hline \multirow{2}{*}{ Related Standard } & Required $\boldsymbol{D U}$ & Observed $\boldsymbol{D U}$ \\
\cline { 2 - 3 } & $\mathbf{( \% )}$ & $\mathbf{( \% )}$ \\
\hline ISO 17831-1 (2015) [44] & $\geq 96.0$ & 97.4 \\
ÖNORM M 7135 (2000) [45] & $<2.3$ & 0.6 \\
\hline
\end{tabular}

DU-mechanical durability.

The volume density $\rho$ showed outstanding results. Compared with the mandatory level, the observed result exceeds it more than two-fold. Similarly, the \% detected amount of fines F was several times below the critical level; a low score is desirable because it means low material losses.

The mechanical durability, $D U$, results are shown separately in Table 10, as it is an important indicator of mechanical quality; as noted above, $D U$ was assessed according to two different methods.

The final bio-pellet samples' mechanical durability DU (\%) according to standard ÖNORM M 7135 (2003) [45] is expressed in the form of the fines percentage after testing, while the mechanical durability DU (\%) according to standard ISO 17831-1 (2015) [44] is expressed in the form of the whole pellets percentage after testing. When both results are expressed according to the standard ISO 17831-1 (2015) [44], the DU are $97.4 \%$ and $99.4 \%$. Both of the observed values indicate fulfilment of the required levels for high-quality produced biofuel, suitable for commercial sale.

Observed values of mechanical durability DU analysed using an ANOVA. The null hypothesis $\mathrm{HO}$ was that there is no statistically significant difference between the different data sets compared to their mean values, i.e., $p>0.05$. The $\mathrm{H}_{0}$ hypothesis was not confirmed, i.e., there was a significant difference ( $p=0.0147$ ) between the results of the mechanical durability DU of the tested bio-pellet samples according to ISO 17831-1 (2015) and ONORM 7165 (2000). 
Results from the literature related to the oil palm EFB bio-pellet fuel mechanical quality are shown in Table 11 and can be compared with the observed result seen in Table 10. All data in Table 11 used EFB bio-pellet fuel with the same diameter as in present investigation $(8 \mathrm{~mm})$.

Table 11. Published results of oil palm EFB bio-pellet fuel mechanical quality.

\begin{tabular}{ccc}
\hline Indicator & Result & Reference \\
\hline$F(\%)$ & 0.35 & {$[54]$} \\
\hline$B D\left(\mathrm{~kg} \cdot \mathrm{m}^{-3}\right)$ & 580.00 & {$[55]$} \\
& 582.45 & {$[17]$} \\
& 441.60 & {$[53]$} \\
\hline$\left(\mathrm{kg} \cdot \mathrm{m}^{-3}\right)$ & 607.00 & {$[54]$} \\
& 980.00 & {$[51]$} \\
& 1040.00 & {$[55]$} \\
& 1140.00 & {$[19]$} \\
& 1245.00 & {$[59]$} \\
\hline & 1023.00 & {$[51]$} \\
& 87.89 & {$[60]$} \\
\hline$F$-amount of fines, $B D$-bulk density, $\rho$ - volume density, DU—mechanical durability.
\end{tabular}

Comparison between data in Tables 9-11 showed a higher mechanical quality of bio-pellet samples produced in present research. Nevertheless, if one considers that the same feedstock material and samples diameter was used, this simply indicates the success and quality of the whole densification process performance.

As indicated in Table 2, the investigated bio-pellet sample dimensions showed some variability, which was not a suitable state for the determination of compressive strength in simple pressure $\sigma_{p}$ and compressive strength in cleft $\sigma_{c}$. The diameter of the bio-pellet samples did not differ extensively, nevertheless, the standard deviation of the diameter $(8.87 \mathrm{~mm})$ was $\pm 0.13 \mathrm{~mm}$, thus, the deviation was approximately about $1.45 \%$. The bio-pellet samples length L $(27.85 \mathrm{~mm})$ standard deviation was $\pm 4.00 \mathrm{~mm}$, about $14.35 \%$. For the purpose of observed values comparability, the bio-pellet samples of similar length L, i.e., $31.45 \pm 2.14 \mathrm{~mm}$, were selected for the determination of the compressive strength in cleft $\sigma_{c}$. The results showed the difference between the achieved values of the tested bio-pellet samples at compressive strength in cleft $\sigma_{\mathcal{c}}\left(60.46 \pm 9.61 \mathrm{~N} \cdot \mathrm{mm}^{-1}\right)$ and compressive strength in simple pressure $\sigma_{p}(10.83 \pm 2.94 \mathrm{MPa})$.

From the point of view of logistics, a substantial simple maximum loading force $F_{\max }$, which differed in case of the compressive strength in cleft $\sigma_{c}(1901.50 \pm 332.47 \mathrm{~N})$ and compressive strength in simple pressure $\sigma_{p}(665 \pm 167.89 \mathrm{~N})$, is essential.

Related to the transportation issue, the study of [61] indicated that interdependencies exist between the place of waste biomass origin and its energy potential within the socio-economic context of the local population. Thus, the fact that investigated waste biomass (oil palm EFB) is available directly at the place of possible utilization indicated that there is no need of transportation, which can cause economic and material losses. Therefore, it increases its suitability as a renewable source of energy, as well as proves its suitability as a feedstock material for biofuel production.

\subsection{Microscopic Analysis}

Stereoscopic microscope observation showed a dominant proportion of fibres with an admixture of tiny particles of various shapes (as seen in Figure 9) in investigated feedstock materials. In general, more than $97 \%$ of the reference sample (randomly selected from feedstock material) has been identified as fibres. 


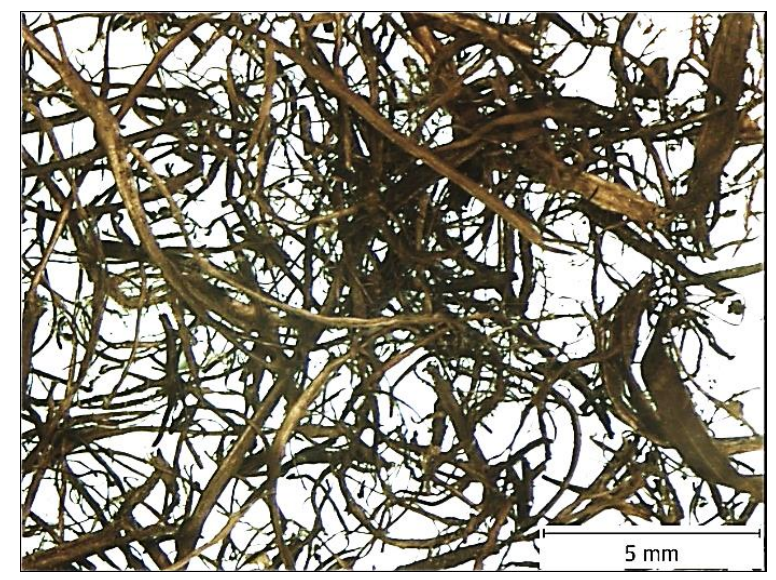

Figure 9. Light microscope view of investigated feedstock materials content.

The surface topography of the EFB fibres and particles are also apparent from the scanning electron microscopy (SEM) pictures shown in the Figure 10a. Figure 10b,c provide a clear, detailed view of representative examples of the most frequently occurring particles.

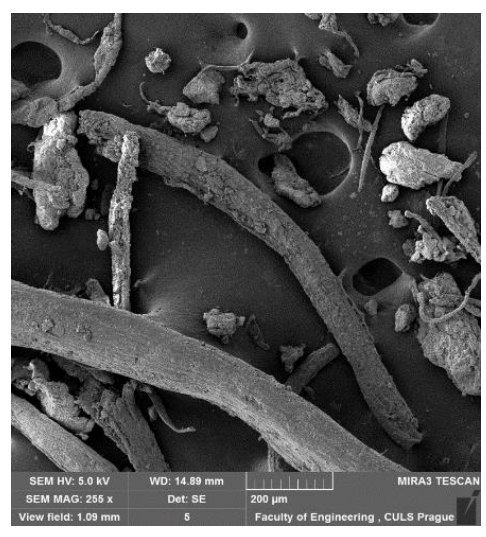

(a)

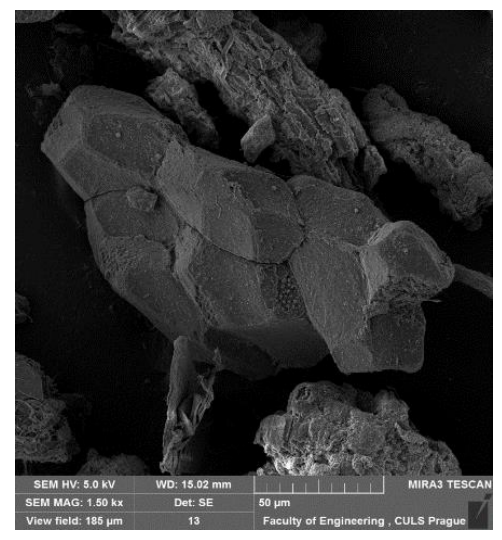

(b)

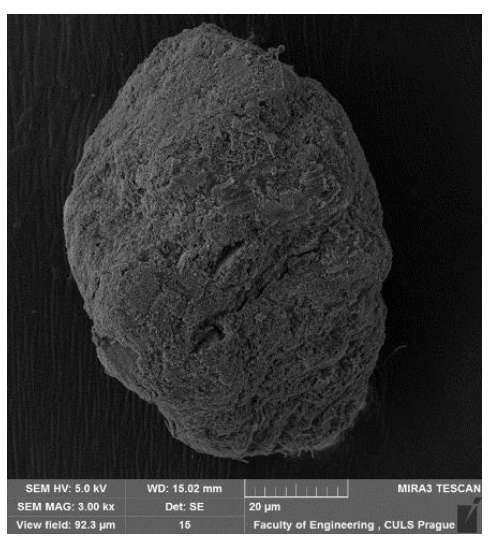

(c)

Figure 10. SEM micrograph of investigated oil palm empty fruit bunches (EFB): (a) Fiber and particles (MAG 225×), (b) segment microparticles (MAG 1.5k $\times$ ) and (c) spherical microparticles (MAG 3.0k $\times$ ).

The outer surface of the produced bio-pellet samples was observed, as shown in Figure 11a,b, as well as the fracture area where the bio-pellet samples were cut off from the densification press (visible in Figure 11c,d).

The macroscopic outer surface of the bio-pellet samples exhibited a regular flat surface (as visible from Figure 11a. The integrity of the surface was disturbed by cracks of different shape, however, as can be seen from Figure 11b. These cracks were diagnosed purely on the outer surface of the bio-pellet samples not within their internal structures. On the contrary, the internal structure of the bio-pellet samples demonstrated a high-quality compacted product, which is evident from Figure 11c,d. The bio-pellet samples exhibited no porosity as well. Figure $11 \mathrm{~d}$ shows densified fibres and a particulate filler is also visible at the top of the image. This particulate filler could not be compacted according to regular shapes. 


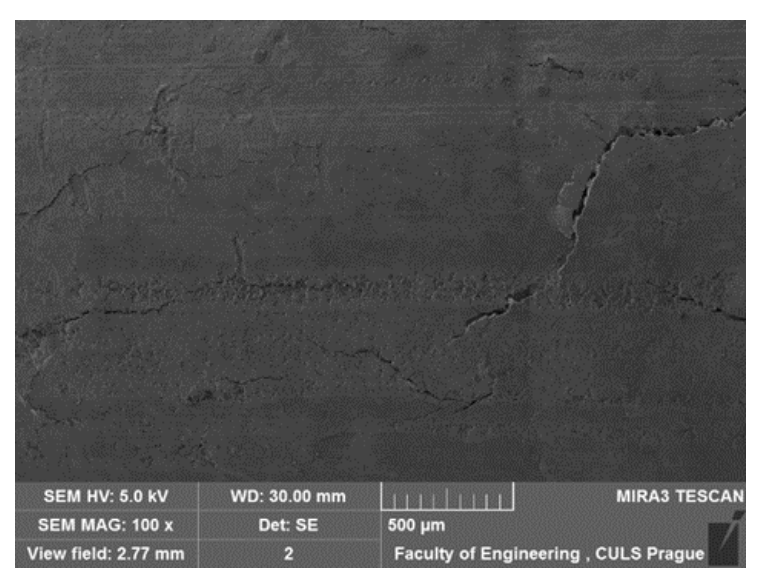

(a)

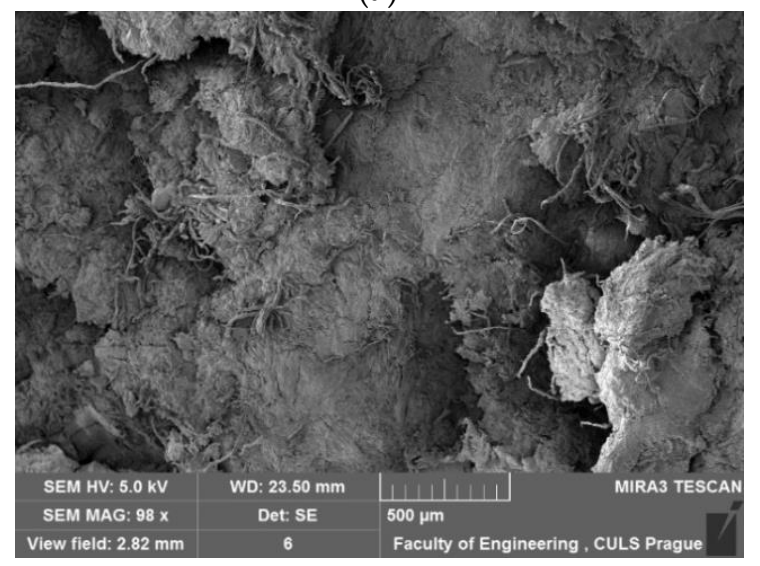

(c)

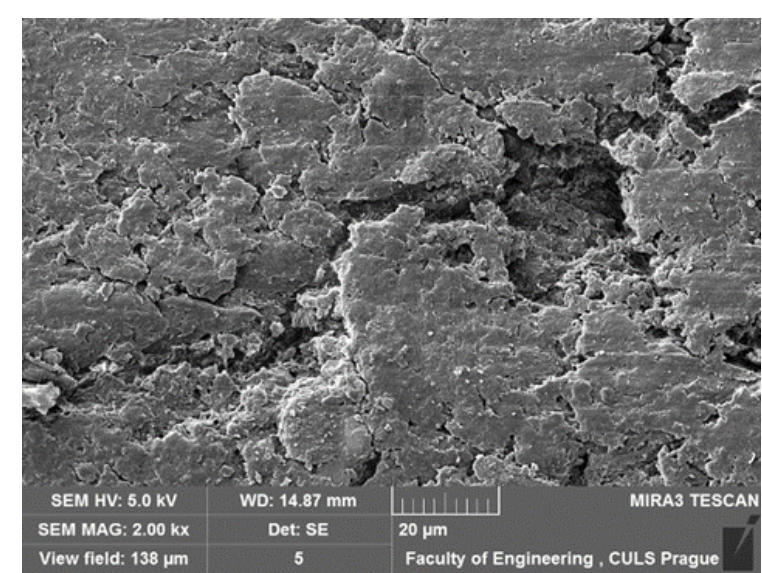

(b)

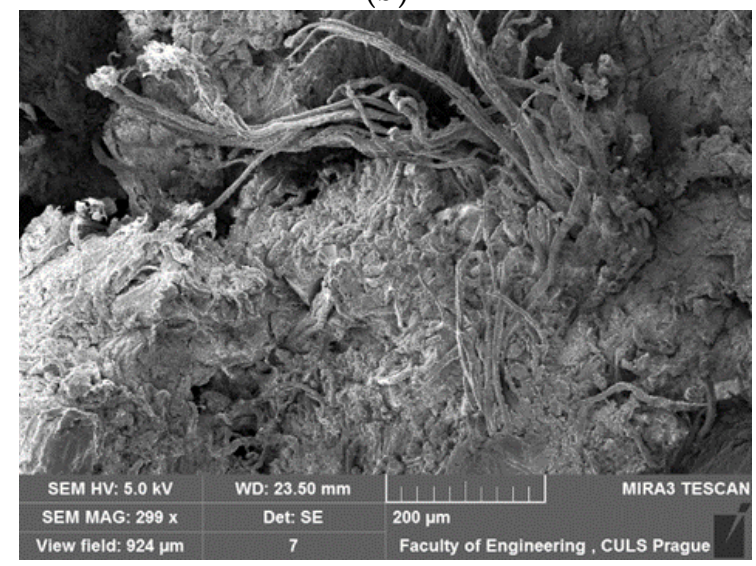

(d)

Figure 11. Scanning electron microscopy cross-section view of investigated bio-pellet samples surface area: (a) Outer surface (MAG $100 \times$ ), (b) detail of the outer surface with apparent inhomogeneity of surface integrity (MAG 2.0k $\times$ ), (c) fracture surface created during production (MAG 98 $\times$ ) and (d) fracture surface created during production (MAG $299 \times$ ).

\section{Conclusions}

The main aim of performed investigation was to determine the suitability of waste biomass from palm oil mill, i.e., primarily composed of oil palm empty fruit bunches (EFB), for the production of bio-pellet fuel. Such investigation was performed in an attempt to mitigate the negative impact of palm oil production on the environment and to support the use of waste biomass (renewable source of energy) for production of clean green energy in the form of biofuels. The safety and harmlessness of such biofuels was tested, thus, complex evaluation of such bio-pellet fuel quality was performed with satisfactory results. Analysis of EFB fuel parameters exhibited satisfactory level of all investigated parameters, except one, the ash content $A_{c}$ (approximately $10 \%$ ), which is the limit of tolerance according to related standard. Thus, such parameter was considered as a limiting factor within the overall evaluation. On the contrary, mechanical quality parameters exhibited outstanding results. Extremely high level of mechanical durability $D U(97.4 \%, 99.4 \%)$ and volume density $\rho$ $\left(1440.01 \mathrm{~kg} \cdot \mathrm{m}^{-3}\right)$ indicated EFB was capable of making high quality bio-pellet fuel and successfully completing the densification process. Microscopic analysis demonstrated strong bonds within the internal structures of produced bio-pellet samples, which indicated high-quality densified biofuel. In general, it can be assumed that the used methodology and its specific steps were adequate for statement of sustainability of bio-pellet fuel produced from EFB.

In conclusion, the overall evaluation indicates high-quality bio-pellet fuel was produced, thus demonstrating the suitability of oil palm EFB for such purposes. Nevertheless, if one considers 
the need for energy production from renewable energy sources (waste biomass) and environmental conservation issues, the subsequent utilization of such waste biomass is sustainable way must be supported. Both energy consumption demands and clean green energy production can be solved by using of the oil palm EFB.

Author Contributions: The following research activities were performed by specific authors: Conceptualization, A.B., M.M. and P.V.; data curation, A.B., M.M., V.Š. and P.V.; formal analysis, A.B.; funding acquisition, A.B.; investigation, A.B., M.M., V.Š., H.A. and P.V.; methodology, A.B., M.M., V.Š. and P.V.; project administration, A.B.; resources, A.B., H.A. and P.V.; validation, A.B.; visualization, A.B.; writing—original draft, A.B.; writing—review and editing, M.M. and P.V.

Funding: The performed research was primarily funded by the Internal Grant Agency of the Czech University Life Sciences Prague (CULS), grant number 20173005 (31140/1313/3108) and by Internal Grant Agency of the Faculty of Engineering, Czech University of Life Sciences Prague (CULS), grant number 2018:31140/1312/3111. Furthermore, the research activities were also supported by the EUROPEAN UNION (EU), managing authority of the Czech Operational Programme Research, Development and Education within the project "Supporting the development of international mobility of research staff at CULS Prague", reg. no. CZ.02.2.69/0.0/0.0/16_027/0008366.

Acknowledgments: In the framework of the performed practical experimental and field research activities implementation, the cooperation of researchers and academic workers of the Faculty of Engineering, Czech University of Life Sciences Prague (CULS), Czech Republic and of the Department of Agroindustrial Technology, University of Lampung (UNILA), Indonesia took place. Additionally, the research was performed thanks to the cooperation between the Department of Material Science and Manufacturing Technology, Faculty of Engineering, Czech University of Life Sciences Prague (CULS), Czech Republic and research center Sustainable Energy and Biomaterial Center of Excellence (SEB COE), Faculty of Engineering, University of Sumatera Utara (USU), Indonesia.

Conflicts of Interest: The authors declare no conflicts of interest.

\section{Nomenclatures}

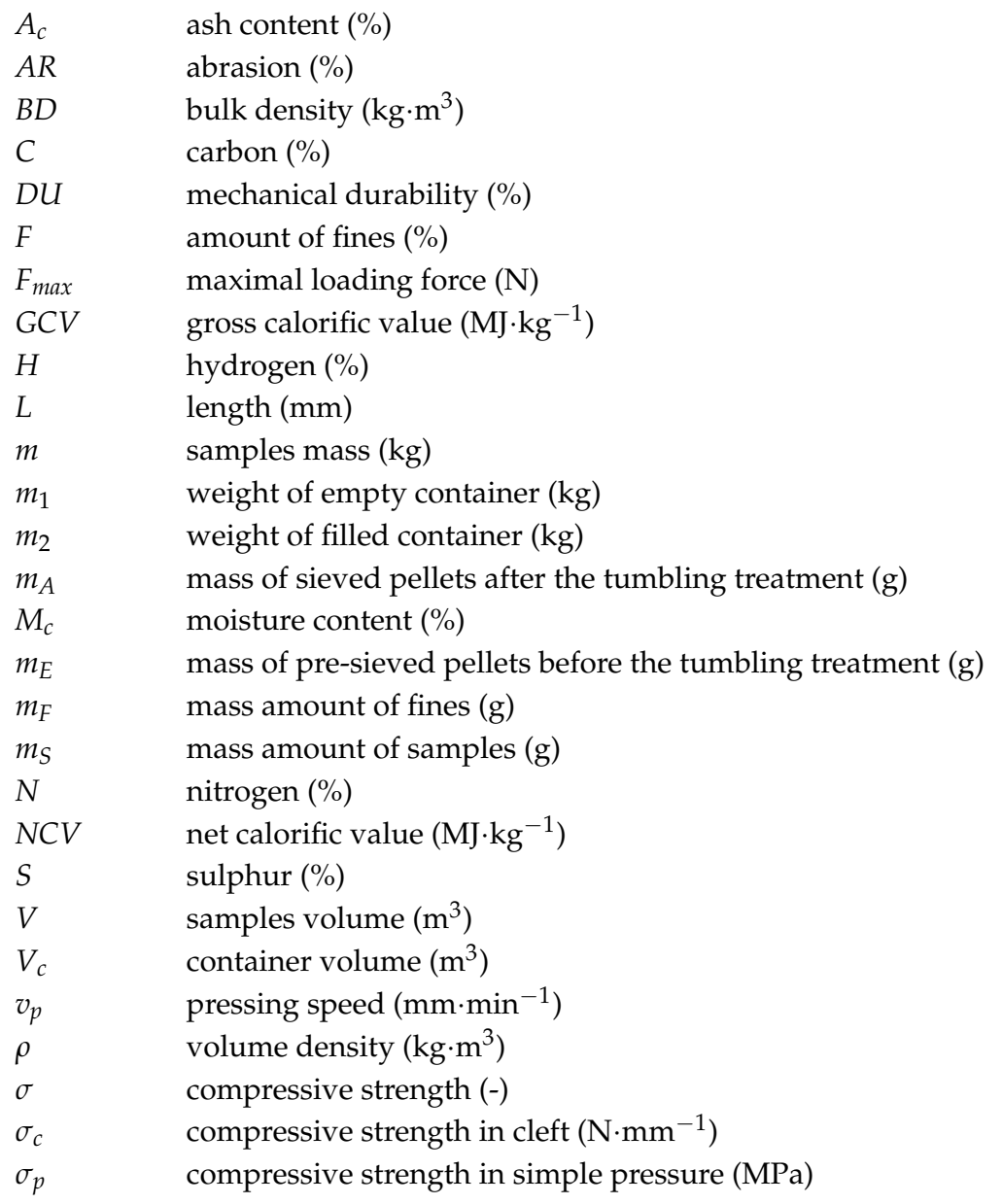




\section{References}

1. Abdul Khalil, H.P.S.; Siti, M.A.; Ridzuan, R.; Kamarudin, H.; Khairul, A. Chemical composition, morphological characteristics, and cell wall structure of Malaysian oil palm fibers. Polym. Plast. Technol. Eng. 2008, 47, 273-280. [CrossRef]

2. Mayes, S. The Oil Palm, 4th ed.; Corley, R.H.V., Tinker, P.B., Eds.; Blackwell Science: Oxford, UK, 2004; Volume xxviii, p. 562.

3. Millennium Ecosystem Assessment (MEA). Ecosystems and Human Well-Being: Biodiversity Synthesis; World Resources Institute: Washington, DC, USA, 2005. Available online: https: / / www.millenniumassessment. org/documents/document.354.aspx.pdf (accessed on 25 September 2018).

4. Fitzherbert, E.B.; Struebig, M.J.; Morel, A.; Danielsen, F.; Brühl, C.A.; Donald, P.F.; Phalan, B. How will oil palm expansion affect biodiversity? Oil palm and biodiversity. Trends Ecol. Evol. 2008, 23, 529-588. [CrossRef] [PubMed]

5. Mahlia, T.M.I.; Abdulmuin, M.Z.; Alamsyah, T.M.I.; Mukhlishien, D. An alternative energy source from palm wastes industry for Malaysia and Indonesia. Energy Convers. Manag. 2001, 42, 2109-2118. [CrossRef]

6. Shinoj, S.; Visvanathanb, R.; Panigrahic, S.; Kochubabua, M. Oil palm fiber (OPF) and its composites: A review. Ind. Crop. Prod. 2011, 33, 7-22. [CrossRef]

7. Hasamudin, W.; Soom, R.M. Road Making Using Oil Palm Fiber. Malaysian Palm Oil Board Information Series; Malaysian Palm Oil Board, Ministry of Primary Industries: Kuala Lumpur, Malaysia, 2002; p. 171. ISSN 1511-7871. Available online: http:/ / palmoilis.mpob.gov.my/publications/TOT/tt171.pdf (accessed on 20 September 2018).

8. Food and Agriculture Organization of the United Nations (FAO). FAOSTAT. Data. Crops. Available online: http:/ / www.fao.org/faostat/en/?\#data/QC (accessed on 25 September 2018).

9. Roslan, A.; Kamarudin, M.F.; Nordin, A.B.A.; Simeh, M.A. A study on the Malaysian oil palm biomass sector-Supply and perception of palm oil millers. Oil Palm Ind. Econ. J. 2011, 11, $28-41$.

10. Malaysian Palm Oil Board (MPOB) [Online]. Statistics. Area and Sectoral Status. Kelana Jaya: Economics \& Industry Development Division. Available online: http:/ / bepi.mpob.gov.my/index.php/en/statistics / production/186-production-2018.html (accessed on 22 August 2018).

11. Abdullah, N.; Gerhauser, H.; Sulaiman, F. Fast pyrolysis of empty fruit bunches. Fuel 2010, 89, $2166-2169$. [CrossRef]

12. Omar, R.; Idris, A.; Yunus, R.; Khalid, K.; Aida Isma, M.I. Characterization of empty fruit bunch for microwave-assisted pyrolysis. Fuel 2011, 90, 1536-1544. [CrossRef]

13. Palamaea, S.; Dechatiwongse, P.; Choorita, W.; Chistid, Y.; Prasertsan, P. Cellulose and hemicellulose recovery from oil palm empty fruit bunch (EFB) fibers and production of sugars from the fibers. Carbohydr. Polym. 2017, 155, 491-497. [CrossRef] [PubMed]

14. Sulaiman, F.; Abdullah, N.; Gerhauser, H.; Shariff, A. An outlook of Malaysian energy, oil palm industry and its utilization of wastes as useful resources. Biomass Bioenergy 2011, 35, 3775-3786. [CrossRef]

15. Chiew, Y.L.; Iwata, T.; Shimada, S. System analysis for effective use of palm oil waste as energy resources. Biomass Bioenergy 2011, 35, 2925-2935. [CrossRef]

16. Chiew, Y.L.; Shimada, S. Current state and environmental impact assessment for utilizing oil palm empty fruit bunches for fuel, fiber and fertilizer-A case study of Malaysia. Biomass Bioenergy 2013, 51, 109-124. [CrossRef]

17. Nasrin, A.B.; Ma, A.N.; Choo, Y.M.; Mohamad, S.; Rohaya, M.H.; Azali, A.; Zainal, Z. Oil Palm Biomass as Potential Substitution Raw Materials for Commercial Biomass Briquettes Production. Am. J. Appl. Sci. 2008, 5, 179-183. [CrossRef]

18. Nyakuma, B.B.; Ahmad, A.; Johari, A. Analysis of the Pyrolytic Fuel Properties of Empty Fruit Bunch Briquettes. J. Appl. Sci. 2012, 12, 2527-2533. [CrossRef]

19. Lam, P.S.; Lam, P.Y.; Sokhansanj, S.; Lim, C.J.; Bi, X.T.; Stephen, J.D.; Pribowo, A.; Mabee, W.E. Steam explosion of oil palm residues for the production of durable pellets. Appl. Energy 2015, 141, 160-166. [CrossRef]

20. Zaini, I.N.; Novianti, S.; Nurdiawati, A.; Irhamna, A.R.; Aziz, M.; Yoshikawa, K. Investigation of the physical characteristics of washed hydrochar pellets made from empty fruit bunch. Fuel Process. Technol. 2017, 160, 109-120. [CrossRef] 
21. Nyakuma, B.B.; Mazangi, M.; Tuan Abdullah, T.A.; Johari, A.; Ahmad, A.; Oladokun, O. Gasification of Empty Fruit Bunch Briquettes in a Fixed Bed Tubular Reactor for Hydrogen Production. Appl. Mech. Mater. 2014, 699, 534-539. [CrossRef]

22. ISO 16559 (2014): Solid Biofuels-Terminology, Definitions and Descriptions; ISO: Geneva, Switzerland, 2014.

23. ISO 17225-6 (2014): Solid Biofuels_Fuel Specifications and Classes_Part 6: Graded Non-Woody Pellets; ISO: Geneva, Switzerland, 2014.

24. ISO 17225-1 (2014): Solid Biofuels_Fuel Specifications and Classes_Part 1: General Requirements; ISO: Geneva, Switzerland, 2014.

25. Maphill. 2018. Available online: http://www.maphill.com/ (accessed on 22 August 2018).

26. ISO 17829 (2015): Solid Biofuels-Determination of Length and Diameter of Pellets; ISO: Geneva, Switzerland, 2015.

27. ISO 18134-1 (2015): Solid Biofuels_Determination of Moisture Content-Oven Dry Method-Part 1: Total Moisture-Reference Method; ISO: Geneva, Switzerland, 2015.

28. ISO 18134-2 (2017): Solid Biofuels_Determination of Moisture Content_Oven Dry Method—Part 2: Total Moisture—Simplified Method; ISO: Geneva, Switzerland, 2017.

29. ISO 18122 (2015): Solid Biofuels-Determination of Ash Content; ISO: Geneva, Switzerland, 2015.

30. ISO 18125 (2017): Solid Biofuels—Determination of Calorific Value; ISO: Geneva, Switzerland, 2017.

31. ISO 1928 (2009): Solid Mineral Fuels_Determination of Gross Calorific Value by the Bomb Calorimetric Method and Calculation of NCV; ISO: Geneva, Switzerland, 2009.

32. ISO 16948 (2015): Solid Biofuels—Determination of Total Content of Carbon, Hydrogen and Nitrogen; ISO: Geneva, Switzerland, 2015.

33. ISO 16994 (2016): Solid Biofuels_Determination of Total Content of Sulfur and Chlorine; ISO: Geneva, Switzerland, 2016.

34. ISO 18135 (2017): Solid Biofuels—Sampling; ISO: Geneva, Switzerland, 2017.

35. ISO 14780 (2017): Solid Biofuels—Sample Preparation; ISO: Geneva, Switzerland, 2017.

36. ISO 18846 (2016): Solid Biofuels_Determination of Fines Content in Quantities of Pellets; ISO: Geneva, Switzerland, 2016.

37. ISO 3310-2 (2013): Test Sieves_Technical Requirements and Testing-Part 2: Test Sieves of Perforated Metal Plate; ISO: Geneva, Switzerland, 2013.

38. ISO 17828 (2015): Solid Biofuels—Determination of Bulk Density; ISO: Geneva, Switzerland, 2015.

39. EN ISO 18847 (2016): Solid Biofuels—Determination of Particle Density of Pellets and Briquettes; ISO: Geneva, Switzerland, 2016.

40. Okot, D.K.; Bilsborrow, P.E.; Phan, A.N. Effects of operating parameters on maize COB briquette quality. Biomass Bioenergy 2018, 112, 61-72. [CrossRef]

41. Seifi, M.R. The moisture content effect on some Physical and Mechanical Properties of Corn. J. Agric. Sci. 2010, 2, 125-134. [CrossRef]

42. Altuntaş, E.; Yıldız, M. Effect of Moisture Content on Some Physical and Mechanical Properties of Faba Bean (Vicia faba L.) Grains. J. Food Eng. 2007, 78, 174-183. [CrossRef]

43. Yahya, A.; Hamdan, K.; Ishola, T.A.; Suryanto, H. Physical and Mechanical Properties of Jatropha curcas L. Fruits from Different Planting Densities. J. Appl. Sci. 2013, 13, 1004-1012. [CrossRef]

44. ISO 17831-1 (2015): Solid Biofuels-Determination of Mechanical Durability of Pellets and Briquettes-Part 1: Pellets; ISO: Geneva, Switzerland, 2015.

45. ÖNORM M 7135 (2003): Compressed Wood or Compressed Bark in Natural State, Pellets and Briquettes. Requirements and Test Specifications; ISO: Geneva, Switzerland, 2003.

46. Rubio, B.; Izquierdo, M.T.; Segura, E. Effect of binder addition on the mechanical and physicochemical properties of low rank coal char briquettes. Carbon 1999, 37, 1833-1841. [CrossRef]

47. ISO 7500-1 (2018): Metallic Materials—Calibration and Verification of Static Uniaxial Testing Machines—Part 1: Tension/Compression Testing Machines-Calibration and Verification of the Force-Measuring System; ISO: Geneva, Switzerland, 2018.

48. García-Maraver, A.; Popov, V.; Zamorano, M. A review of European standards for pellet quality. Renew. Energy 2011, 36, 3537-3540. [CrossRef]

49. Mohamed, A.R.; Lee, K.T. Energy for sustainable development in Malaysia: Energy policy and alternative energy. Energy Policy 2006, 34, 2388-2397. [CrossRef] 
50. Vijaya, S.; Chow, M.C.; Ma, A.N. Energy Database of the Oil Palm. MPOB Palm Oil. Eng. Bull. 2004, 70, $15-22$.

51. Nurdiawati, A.; Novianti, S.; Zaini, I.N.; Sumida, H.; Yoshikawa, K. Production of low-potassium solid fuel from empty fruit bunches (EFB) by employing hydrothermal treatment and water washing proces. J. Jpn. Inst. Energy 2015, 94, 775-780. [CrossRef]

52. Harun, N.Y.; Parvez, A.M.; Afzal, M.T. Process and Energy Analysis of Pelleting Agricultural and Woody Biomass Blends. Sustainability 2018, 10, 1770. [CrossRef]

53. Uemura, Y.; Omar, W.N.; Tsutsui, T.; Yusup, S.B. Torrefaction of oil palm wastes. Fuel 2011, 90, $2585-2591$. [CrossRef]

54. Rahman, N.A.; Atan, M.F.; Low, C.M.; Baini, R.; Che Mat, N.F.; Salleh, S.F. Study on the Potential of Pelletisation of Empty Fruit Bunch with Sago as Binding Agent for Power Generation. Eur. Int. J. Sci. Technol. 2013, 2, 111-118.

55. Erlich, C.; Fransson, T.H. Downdraft gasification of pellets made of wood, palm-oil residues respektive bagasse: Experimental study. Appl. Energy 2011, 88, 899-908. [CrossRef]

56. Gravalos, I.; Xyradakis, P.; Kateris, D.; Gialamas, T.; Bartzialis, D.; Giannoulis, K. An Experimental Determination of Gross Calorific Value of Different Agroforestry Species and Bio-Based Industry Residues. Nat. Resour. 2016, 7, 57-68. [CrossRef]

57. Miranda, T.; Montero, I.; Sepúlveda, F.J.; Arranz, J.I.; Rojas, C.V.; Nogales, S. A Review of Pellets from Different Sources. Materials 2015, 8, 1413-1427. [CrossRef] [PubMed]

58. Obernberger, I.; Thek, G. Physical characterisation and chemical composition of densified biomass fuels with regard to their combustion behaviour. Biomass Bioenergy 2004, 27, 653-669. [CrossRef]

59. Núñez, C.A.F.; Jochum, J.; Vargas, F.E.S. Characterization and feasibility of biomass fuel pellets made of Colombian timber, coconut and oil palm residues regarding European standards. Environ. Biotechnol. 2012, 8, 67-76.

60. Talero, G.F.; Rincon, S.L.; Gonzalez, A. Use of Colombian Oil Palm Wastes for Pellets Production: Reduction of the Process Energy Consumption by Modifying Moisture Content. In Proceedings of the 6th International Conference on Engineering for Waste and Biomass Valorisation, Albi, France, 23-26 May 2016.

61. De Santoli, L.; Mancini, F.; Nastasi, B.; Piergrossi, V. Building integrated bioenergy production (BIBP): Economic sustainability analysis of Bari airport CHP (combined heat and power) upgrade fueled with bioenergy from short chain. Renew. Energy 2015, 81, 499-508. [CrossRef] 